\title{
Editorial: Asia Pacific Journal on Computational Engineering
}

Nguyen Dang Hung ${ }^{1,2}$

Correspondence:

h.nguyendang@ulg.ac.be

${ }^{1}$ University of Liège, Liège, Belgium

${ }^{2}$ Vietnamese-German University, Binh Duong New City, Binh Duong

Province, Vietnam

\section{Editorial}

During my long career of 40 years as a researcher and professor at the University of Liège, Belgium, I have always been interested in running a scientific journal in my field. But due to lack of time, I had put on hold this hot desire. Indeed, during the last 20 years in activity, I pursued the dual functions of permanent full professor in Belgium and founder professor coordinator of the two centers of international interuniversity Master's degree training in Ho Chi Minh City and Hanoi, Vietnam.

It is only during my retirement where I returned to Vietnam, that I have the time to start working on this idea, initially receiving effective encouragement by the leaders of Ton Duc Thang university. It was during the period when I was senior advisor of this university that the founding agreement with Springer was signed, and APJCEN could appear as you see today.

When the Asia Pacific Journal on Computational Engineering (APJCEN) was opened for submissions in 2013, I was aware of the difficulties caused by the current competition in this sector of scientific information, especially with the open-access format that is not yet very attractive to researchers in the world. Nevertheless, encouraged by the support of more than 50 leading scientists from around the world and especially the partnership agreement of the famous publisher Springer, the advent of APJCEN has finally emerged as you see today.

APJCEN has set out as an international multidisciplinary peer-reviewed publication devoted to disseminating research in and development of theoretical and applied mechanics. APJCEN constitutes a forum for researchers to present their original work and scholarly reviews of solid mechanics, fluid mechanics, structural mechanics, material modeling, multiphysics, and thermodynamics with significant computational components. The journal will adopt a multidisciplinary approach to link physical, experimental, and mechanics as applied to the development of and practice in computational engineering. The journal is committed to providing comprehensive and innovative techniques in computational engineering.

The regional denomination means only that the secretariat team is located in Asia, but you may recognize that the list of editorial board consists of renowned scientists from around the world!

In fact, this dissemination of computational methods and their applications should impact research and education at universities, as well as developments in research institutions and industries throughout the Asia Pacific Region, mostly in ASEAN countries, and particularly in Vietnam. We hope that the journal will attract young researchers to

(C) 2014 Dang Hung; licensee Springer. This is an Open Access article distributed under the terms of the Creative Commons Attribution License (http://creativecommons.org/licenses/by/4.0), which permits unrestricted use, distribution, and reproduction in any medium, provided the original work is properly credited. 
publish their results and motivate them to use computational methods and software in various fields of science and engineering.

I am very pleased that this first issue of APJCEN appears at the beginning of the New Year 2014 and should be promising for a stable and prosperous development in the future.

Received: 10 February 2014 Accepted: 10 February 2014

Published: 29 April 2014

doi:10.1186/2196-1166-1-1

Cite this article as: Hung: Editorial: Asia Pacific Journal on Computational Engineering. Asia Pacific Journal on

Computational Engineering 2014 1:1.

Submit your manuscript to a SpringerOpen ${ }^{\circ}$ journal and benefit from:

- Convenient online submission

- Rigorous peer review

- Immediate publication on acceptance

- Open access: articles freely available online

- High visibility within the field

- Retaining the copyright to your article

Submit your next manuscript at $>$ springeropen.com 